\title{
Аматорський спорт як засіб запобігання емоційному вигоранню
}

\author{
УДК 796+612.821+154.6
}

\section{С. В. Тукаєв ${ }^{1}$, Т. В. Вашека², О. М. Долгова², Н. І. Погорільська ${ }^{3}$, Д. Д. Иваскевич ${ }^{1}$, С. В. Федорчук ${ }^{1}$}

${ }^{1}$ Науково-дослідний інститут Національного університету фізичного виховання і спорту України, Київ, Україна

${ }^{2}$ Національний авіаційний університет, Київ, Україна

${ }^{3}$ Київський національний університет імені Тараса Шевченка, Київ, Україна

Резюме. Мета. Встановити значення аматорського спорту як основи копінга емоційного вигорання у студентської молоді, виявити психологічні особливості студентів, які визначають уразливість до стрес-умов і схильність до формування емоційного вигорання. Методи. Психодіагностична процедура була розділена на чотири частини: вимірювання емоційного вигорання, дослідження індивідуально-типологічних властивостей, визначення психічного стану респондентів та їх емоційних реакцій, діагностики антиципаційних здібностей. Результати. Встановлено, що заняття аматорськими видами спорту допомагають запобігти емоційному вигоранню у студентів. За всіма показниками в групі спортсменів-любителів і симптоми, і фази емоційного вигорання менш виражені. Редукція особистісних досягнень за методикою К. Маслач більше виражена в групі спортсменів, що можна пояснити можливими розчаруваннями як в навчальній діяльності, так і незадоволеністю спортивними успіхами. Можна стверджувати, що спорт має сильний позитивний вплив на емоційний і психічний стан людини, захищаючи психіку від дії стресорів, навчаючи спортсменів справлятися з труднощами, привносячи гармонію у фізичне і психічне буття.

Ключові слова: любительський спорт, емоційне вигорання, індивідуально-психологічні та типологічні властивості особистості.

\section{Amateur sport as a means of preventing emotional burnout}

\section{S. V. Tukaiev', T. V. Vasheka ${ }^{2}$, O. M. Dolhova ${ }^{2}$, N. I. Pohorilska ${ }^{3}$, D. D. Yvaskevych',} S. V. Fedorchuk ${ }^{1}$

${ }^{1}$ Scientific and Research Institute of the National University of Physical Education and Sport of Ukraine, Kyiv, Ukraine

${ }^{2}$ National Aviation University, Kyiv, Ukraine

${ }^{3}$ Taras Shevchenko National University of Kyiv, Kyiv, Ukraine

Abstract. Objective. To determine the significance of an amateur sport as the basis of emotional burnout coping in university students and reveal student psychological peculiarities that define the vulnerability to stressful conditions and the tendency to form emotional burnout. Methods. The psychodiagnostic procedure was divided into four parts: measurement of emotional burnout, study of individual-typological properties, determination of the mental state of respondents and their emotional reactions, diagnosis of anticipatory abilities. Results. It has been established that practicing amateur sports helps to prevent emotional burnout in students. The data support the initial assumption that the group of sport amateurs have less pronounced symptoms of burnout in comparison to those who do not practice any sport. However, the index of the reduction of personal achievements according to K. Maslach methods was more significant in the group of athletes, which can be explained by possible disappointment in studying activities and dissatisfaction with achievements in sport. It can be concluded that practicing sports has a strong positive impact on the emotional and mental state of a person, protects an individual from stress factors, helps athletes to cope with difficulties, and brings harmony to one's physical and mental being. 
Keywords: amateur sport, emotional burnout, individual-psychologycal and typological features of personality.

Постановка проблеми. Емоційне вигорання $\epsilon$ однією з форм професійного стресу і веде до серйозних руйнівних наслідків для суспільства, організацій, а також міжособистісних і сімейних відносин через психічні та поведінкові зміни. Відповідно до моделі К. Маслач, синдром вигорання включає три компоненти: емоційне виснаження, деперсоналізацію і редукцію персональних досягнень. Центральне місце в цій тріаді посідає емоційне виснаження, яке проявляється у відчутті спустошення, емоційного перенапруження, виснаження власних ресурсів. Деперсоналізація проявляється в цинічному, бездушному відношенні до членів сім'ї, друзів, співробітників, клієнтів або інших суб'єктів діяльності. Міжособистісне спілкування стає формальним і знеособленим. Редукція персональних досягнень, у свою чергу, проявляється як знецінення своєї діяльності, в почутті безглуздості, незадоволеності роботою, своїми професійними успіхами [23]. За визначенням В. Бойка, емоційне вигорання - механізм психологічного захисту у вигляді повного або часткового відключення емоцій у відповідь на психотравмуючі впливи. Це набутий стереотип емоційної, частіше професійної, поведінки, що $є$ проявом професійної деформації особистості. В. Бойко розглядає вигорання як динамічний процес, що виникає поетапно відповідно до механізму розвитку стресу і який проходить три фрази: тривожної напруги, резистенції і виснаження [2]. Основними індивідуально-типологічними детермінантами емоційного вигорання $є$ високий рівень невротизації, нейротизму, інтроверсія, а також слабкість процесів збудження, гальмування і низька рухливість нервових процесів $[4,25$, 26,34-36]. Більш високі рівні тривожності зумовлюють ризик розвитку вигорання у спортсменів [27].

У психології спорту концепція вигорання надзвичайно популярна $[7,8,11,14,15,21,27,28$, $37,38]$. Явище вигорання в спортивному контексті представляє інтерес з 1970-х років [12]. Важливість, актуальність проблеми підкреслюється тим фактом, що серед основних тем дослідницьких проєктів в 25 кращих бразильських університетах з 2002 по 2012 р. чотири проєкти були присвячені вигоранню [32]. Згідно з Еклундом і Дефррізом тільки деякі спортсмени відчувають вигорання в своїй спортивній кар'єрі [12]. Більшість дослідників зосередили увагу на елітних і висококваліфікованих спортсменах, дорослих і підлітках. Розвиток вигорання був досліджений у профресійних спортсменів (елітних канадських спортсменів [20], регбістів [7, 8], гравців у настільний теніс [21], футболістів [22, 37], гандболістів [17], тренерів, спортивних суддів, рефері $[16,19,29]$, спортивних чиновників [30], у той час як проблеми вигорання серед спортсменіваматорів, особливо високого рівня, недостатньо досліджені [8]. На наш погляд, тут ситуація з вигоранням буде протилежною, оскільки під час занять аматорськими видами спорту людина не відчуває настільки сильного тиску, необхідності будь-якою ціною завоювати перемогу, а спорт приносить скоріше задоволення, так як спортсмени-любителі займаються ним заради самого процесу участі в спортивних іграх, клубах, командах, а не заради перемоги.

Так, К. Гудгер зі співавт. [14; 15] та П. Віллеман і Д. Лаваль [38] проаналізували наукову літературу про вигорання в спорті й зазначили, що увагу практично в рівній мірі приділяють спортсменам і тренерам, батькам і спортивним фрункціонерам, а також психологічним, демографічним і ситуативним чинникам. Зазначено, що 3 інтенсивними тренуваннями і змаганнями пов'язане фрізичне та емоційне виснаження. Вигорання спортсменів переважно викликано поганою практикою подолання проблем та несформованими навичками їх вирішення [28]. Знижене відчуття досягнення поставлених цілей пов'язане з майстерністю, вміннями і здібностями атлетів. Тому вони не здатні виступати вище своїх можливостей. У контексті спорту наслідки вигорання впливають не тільки на здоров'я і самопочуття спортсменів, а й на їх виступи [14]. Стрес і вигорання мають найбільший вплив на майбутні (наприклад, у наступному місяці) виступи молодих спортсменів у зв'язку зі зниженням почуття виконаного обов'язку [21]. Зниження відчуття виконаного обов'язку зменшується із розвитком профресіоналізму, «дозрівання» спортсменів, тоді як траєкторія «емоційного/фрізичного виснаження» збігається з рівнем «спортивної девальвації» [17]. Стійкість до стресу, здатність швидко відновлювати фрізичний і душевний стан, адекватно реагувати на невдачі, долати перешкоди мають важливе значення для будь-якого успішного спортсмена [13].

Створено кілька моделей розвитку вигорання у спортсменів. Деякі теорії зосереджені на відмінностях вигорання від перетренованості і 
втоми [14]. Когнітивно-афективна модель Сміта (Smith's cognitive-affective model of athlete burnout) передбачає, що вигорання $\epsilon$ результатом хронічного стресу, розвивається паралельно йому і проявляється через взаємини між ситуативними фракторами і когнітивною оцінкою взаємодії людина-ситуація, фрізіологічними реакціями (що відносяться до оцінки) і поведінковими реакціями. Ці компоненти вигорання залежать від мотиваційних і особистісних фракторів.

Організаційні питання (проблеми) в спорті лежать в основі соціологічного пояснення вигорання Коклі (Coakley), а саме: відбуваються втрата ідентичності та незалежності, розвиток одномірності у молодих спортсменів [6, 14]. Згідно з Коклі [6], першопричина вигорання у молодих спортсменів - соціальна організація спорту вищих досягнень, і залежить вона від рис особистості й питань контролю. У теорії Шмідта і Штейна, заснованій на понятті «почуття обов'язку» (Commitment-based model of Schmidt and Stein), вигорання це не просто реакція на стрес, а обов'язок спортсмена на змаганнях бути більше, ніж тим, ким він $\epsilon$, тому що повинен, незалежно хоче він цього чи ні («have to be» rather than «want to be» - «повинні бути», а не «хочу бути») [14]. Вигорання як результат безперервних перевантажень на тренуваннях («перетренованості»), негативних відповідей на дезадаптацію до тренувань лежить в основі моделі Сільви (Silva) [14]. B основу багатьох теорій закладено прагнення відрізняти вигорання від перетренованості й перевтоми [14].

Також підкреслюється важливість ролі тренера в розвитку вигорання у його підопічних [9]. Серед основних причин вигорання у спортсменів Верарді зі співавт. [37] виокремлюють стиль тренера, високі конкурентні вимоги, стратегії конфрронтації, зовнішній образ життя, монотонність навчання і відсутність позитивного підкріплення. До найбільш явних негативних проявів вигорання у спортсменів відносять втрату внутрішньої мотивації, відсутність задоволення у виступах, тренуваннях, неефективні моделі, способи боротьби зі стресом, високий рівень тривоги і недостатнє повільне відновлення, переживання низької соціальної підтримки $[5,7,8,14]$.

Одним із пояснень розвитку вигорання у спортсменів $\epsilon$ теорія самовизначення (selfdetermination theory, SDT). SDT фокусується на поведінці на основі вільного вибору, внутрішніх і зовнішніх джерелах мотивації, властивості особистості. Мотивація визначається трьома основними і універсальними базовими психологічними потребами: автономією, компетентністю і пов'язаністю. Хронічна недосяжність цих основних потреб призводить до розвитку вигорання $[10,31]$. В рамках цієї концепції компетентність пов'язана зі «зменшеним почуттям виконаного обов'язку», яке відображає когнітивну складову емоційного вигорання, оскільки воно пов'язане з оцінкою спортсменами досягнення мети, того що можна і потрібно зробити для перемоги $[20,24]$.

Мета дослідження - визначити аматорський спорт як основу копінгу емоційного вигорання у студентської молоді. Також у цьому дослідженні ми зосередилися на психологічних особливостях студентів, які визначають уразливість до стресумов і схильність до фрормування емоційного вигорання.

Зв'язок роботи з науковими програмами, планами, темами. Дослідження виконано відповідно до держбюджетної науково-дослідної теми «Технологія оцінки ризику травматизму спортсменів за електронейроміографічними і психофрізіологічними показниками» (номер держреєстрації 0119U000307) Міністерства освіти і науки України.

Методи дослідження. Об'єктом обстеження були 348 здорових добровольців (94 чоловіка і 254 жінки віком від 17 до 23 років, Mage $=18$, $S D=1,24)$, студенти першого курсу Київського національного університету імені Тараса Шевченка, Навчально-наукового центру «Інститут біології і медицини» та фракультету психології. Учасники мали право на участь у дослідженні, якщо їх вік перевищував 17 років і вони не мали клінічних проявів психічних або когнітивних порушень. Серед критеріїв виключення були: прийом психоактивних ліків, наркотична або алкогольна залежність, а також психіатричні або неврологічні скарги.

Студенти були розподілені на дві групи за рівнем рухової активності. До групи "Спортсмени» входило 67 осіб (33 чоловіки та 34 жінки) у віці від 17 до 23 років $(M=18, S D=1,57)$, які регулярно займалися спортом (спортивний стаж 2-7 років), причому як командними видами (футбол, волейбол), так і індивідуальними (легка атлетика, плавання). До контрольної групи увійшли студенти, які не мали досвіду занять спортом, крім уроків фрізкультури в школі і вузі. Причому їх кількість серед студентів психологів і біологів значно перевищує тих, хто займається спортом: 281 студент (220 жінок і 61 чоловік віком від 17 до 23 років, $M=18, S D=1,13)$. Студенти були обізнані про зміст тестів і дали згоду на їх проведення.

Психодіагностичне дослідження. Психодіагностична процедура була розділена на чотири частини. 
1. Для вимірювання емоційного вигорання у студентів було використано опитувальник емоційного вигорання Христини Маслач (Maslach Burnout Inventory, MBI), що містить 22 пункти, i тест «Синдром емоційного вигорання В. Бойка», що містить 84 пункти, адаптований для професійної групи студентів С. Тукаєвим і Т. Вашекою $[1,4]$.

Існує два підходи до визначення синдрому емоційного вигорання. Тест В. Бойка «Синдром емоційного вигорання» складається з трьох фраз, які розглядають зміни параметрів психологічної та емоційної активності: тривожна напруга, резистенція і виснаження [2]. Значення кожної $з$ цих фраз вимірюється за шкалою від 0 до 120: від 0 до 36 пунктів - фраза не сформована, від 37 до 60 - фаза знаходиться на етапі формування, від 61 до 120 - фраза сформована. Х. Маслач описує вигорання як процес, і людина знаходиться на одному з етапів вигорання. Синдром вигорання розвивається, коли особистих ресурсів недостатньо, щоб справлятися з постійним стресом в роботі і в міжособистісних відносинах. Тест Маслач (Maslach Burnout Inventory, MBI) призначений для діагностики вигорання на роботі (професійного вигоряння) і складається з таких трьох компонентів: емоційне виснаження, деперсоналізація i редукція особистих досягнень [2; 23].

Синдром вигорання у професійних спортсменів пов'язаний з надмірними вимогами, що пред'являються навчанням, конкуренцією і ефективністю. У спортивній психології $€$ кілька психометричних інструментів для вимірювання даного типу вигорання. Для визначення стресу i вигорання у спортивних чиновників застосовують Стрес-опитувальник офріційних осіб футболу (The Soccer Officials' Stress Survey) [33]. Т. Редеке і А. Сміт розробили опитувальник вигорання у спортсменів (The Athlete Burnout Questionnaire, ABQ) спочатку для оцінки синдрому вигорання переважно у підлітків-спортсменів високого рівня, а потім вже було схвалено і адаптовано версію для оцінки вигорання у спортсменів з різних видів спорту [27]. Верарді зі співавт. [37] використовували версію $\mathrm{ABQ}$ для оцінки рівня синдрому вигорання і фракторів ризику бразильських орутболістів. А. Ламонт-Міллс зі співавт. [18] застосували $A B Q$ до більш широкого кола видів спорту (хокей на траві, регбі, нетбол, баскетбол, гольф, футбол, вітрильний спорт, плавання). Т. Редеке і А. Сміт описували вигорання відповідно до тривимірної концептуалізації вигорання Х. Маслач 3 фокусом на спорті: зменшене почуття спортивних досягнень і девальвація/почуття образи від спорту, емоційне/фрізичне виснаження, а також фрактори-змінні пов'язані зі стресом і мотивацією $[11,27]$. Використання $\mathrm{ABQ}$ зі спортсменами-підлітками виявило ряд проблем, пов'язаних зі зменшенням почуття виконаного обов'язку. Переоцінка психометричних властивостей вихідного трьохфакторного $\mathrm{ABQ}$ вказує на те, що ця модель не прийнятна в частині, що приписується позитивному фрормулюванню питань, баченню стану справ (зокрема, здатність до досягнення, успішність у спорті) [18].

Крім того, ці вищезгадані опитувальники направлено не оцінювали вплив освітніх фракторів на розвиток вигорання спортсменів-любителів. Слід зазначити, що вигорання спортсменів здійснюється за мотивами самовизначення [20, 22]. Раніше було показано, що мотиваційна, семантична і комунікативна сорери студентів визначають формування синдрому емоційного вигорання під час навчання [4, 34]. Ми припустили, що обидва опитувальники (стрес-опитувальник офріційних осіб фрутболу (The Soccer Officials' Stress Survey) і опитувальник вигорання у спортсменів (The Athlete Burnout Questionnaire, ABQ), на відміну від тестів Маслач і Бойка не підходять для дослідження вигорання у любителів, оскільки причини його виникнення виходять за межі спортивного майданчика.

2. 3 метою дослідження індивідуально-типологічних властивостей застосовували методики Я. Стреляу і Г. Айзенка (ЕРі). Тести з діагностики темпераменту, розроблені Я. Стреляу і Г. Айзенком (EPi), вказують на окремі типологічні характеристики. Ці методи дозволили визначити силу процесів збудження і гальмування, рухливість та переключення нервових процесів і рівень екстраверсії-інтроверсії і нейротизму.

Особистісна шкала прояву тривоги Дж. Тейлор (TMAS, адаптація методики Т. А. Нємчинова) вимірює тривогу як спільну рису особистості.

Шкала тривоги 4. Спілбергера (State-Trait Anxiety Inventory, STAI, адаптована Ю. Ханіним) $\epsilon$ інфоормативним способом самооцінки як рівня тривожності в даний момент (реактивна тривожність як стан), так і особистісної тривожності (як стійка характеристика людини). Тест Ч. Спілбергера визначає рівень тривоги на основі шкали самооцінки (висока, середня, низька тривога). Ситуативна тривожність виникає як реакція на соціально-психологічні стресори. Особистісна тривожність дає уявлення про індивідуальну сприйнятливість до стресу за особистісними психологічними характеристиками.

3. Щоб визначити психічний стан респондентів та їх емоційні реакції було використано такі тести: 
Шкала UN (опитувальник Вассермана для експрес-діагностики рівня невротизації) дозволяє оцінити ймовірність появи невротичних епізодів (діагностична шкала) і соціальної бажаності (контрольна шкала). Сім ступенів тесту показують високий або низький рівень невротизації.

Методика диференціальної діагностики депресії В. А. Жмурова спрямована для виявлення переважно депресивних настроїв або меланхолійної депресії і дозволяє встановити тяжкість депресії в даний момент за шкалою від 1 до 132 балів: від 1 до 9 балів - депресія не сорормована, від 10 до 24 - депресія мінімальна, від 25 до 44 - легка депресія, від 45 до 67 - помірна депресія, від 68 до 87 - виражена депресія, від 88 до 132 - значна депресія.

Методика діагностики емоційної відповіді на навколишні подразники В. Бойка дозволяє визначити домінуючий тип емоційної реакції. Це метод трансформації внутрішніх і зовнішніх впливів у позитивні, нейтральні або негативні енергетичні стани і поведінкові акти. У тесті розглянуто два параметри: тип емоційної реакції (зовнішні ейфорійні, внутрішні рефрактерні і зовнішні диссроричні типи емоційної реакції) і характер подразників (позитивний, нейтральний або амбівалентний, негативний).

Бостонський тест стресостійкості (соціальний стрес-тест «Аналіз способу життя») визначає вразливість до стресових ситуацій під впливом життєвої напруги.

Методика психологічного стресу ЛемурТессьє-Філліон (Lemur-Tessier-Fillion, PSM25) дозволяє оцінити поточний рівень стресу, пов'язаного з роботою, за 8-бальною шкалою Лікерта (від «немає взагалі» до «дуже вірогідні») від 25 до 200 балів. Підраховують суму всіх відповідей - інтегральний показник психічної напруженості (ППН). Чим більше ППН, тим вищий рівень психологічного стресу.

Тест агресивної поведінки $Є$. П. Ільїна і П. А. Ковальова призначений для виявлення схильності до певного типу агресивної поведінки (схильність до прямої і непрямої вербальної агресії, схильність до прямої і непрямої фізичної агресії, рівень експансивності). Інтегральний тест-індикатор (експансивність) діагностують понад 20 пунктів.

4. Для діагностики антиципаційних здібностей було використано методику вивчення прогностичної компетентності (антиципаційної спроможності) В. Д. Менделевича, що дозволяє визначити такі показники, як загальна антиципаційна здатність, ситуаційно-особистісна антиципація, просторова й часова антиципація, а також методику «Здатність до прогнозування» Л. А. Регуш. За- значена методика передбачає визначення швидкості мислення; рівня аналітичного мислення; реалізації; гнучкості мислення; перспективності; обгрунтованості; схильності до ризику.

Результати дослідження та їх обговорення. Чи можуть спорт, тренування, фрізичні навантаження захистити від стресу - тут дані психологічних і фрізіологічних досліджень дають неоднозначну відповідь. У психології спорту психологічні стресові розлади у спортсменів стають все більш важливою областю досліджень. Аналізуючи отримані нами результати, можна припустити, що заняття аматорськими видами спорту позитивно впливають на стресостійкість особистості і дозволяють краще справлятися зі стресом $[3,35]$. Як і очікувалося, заняття аматорськими видами спорту допомагають запобігти емоційному вигоранню у студентів (табл. 1).

За всіма показниками в групі спортсменів-любителів і симптоми, і фрази емоційного вигорання менш виражені, крім шкали «редукція особистісних досягнень за методикою К. Маслач». Останній показник більше виражений у групі спортсменів, що можна пояснити можливими розчаруваннями у навчальній діяльності і незадоволеністю спортивними успіхами. Незважаючи на цей одиничний виняток, можна стверджувати, що спорт має сильний позитивний вплив на емоційний і психічний стан людини, захищаючи психіку від дії стресорів, навчаючи спортсменів справлятися з труднощами, привносячи гармонію у фрізичне і психічне буття.

ТАБЛИЦЯ 1 - Порівняння груп за рівнем емоційного вигорання

\begin{tabular}{|c|c|c|c|}
\hline \multirow[b]{2}{*}{ Показники } & \multicolumn{2}{|c|}{ Середнє по групі } & \multirow{2}{*}{$\begin{array}{c}\text { Рівень } \\
\text { значущості } \\
\text { відмінностей } \\
\text { між групами }\end{array}$} \\
\hline & $\begin{array}{c}\text { Група } \\
\text { «Спортсмени» }\end{array}$ & $\begin{array}{c}\text { Контрольна } \\
\text { група }\end{array}$ & \\
\hline \multicolumn{4}{|c|}{ Методика К. Маслач } \\
\hline $\begin{array}{l}\text { Емоційне } \\
\text { виснаження }\end{array}$ & 21,0 & 23,2 & 0,04 \\
\hline $\begin{array}{l}\text { Редукція } \\
\text { особистісних } \\
\text { досягнень }\end{array}$ & 32,6 & 30,6 & 0,05 \\
\hline \multicolumn{4}{|c|}{ Тест В. Бойка } \\
\hline $\begin{array}{l}\text { Незадоволеність } \\
\text { собою }\end{array}$ & 4,5 & 6,1 & 0,05 \\
\hline Тривога і депресія & 6,6 & 9,0 & 0,039 \\
\hline Фаза напруги & 19,6 & 25,3 & 0,046 \\
\hline $\begin{array}{l}\text { Емоційно- } \\
\text { моральна } \\
\text { дезорієнтація }\end{array}$ & 8,6 & 10,8 & 0,015 \\
\hline $\begin{array}{l}\text { Психосоматичні та } \\
\text { психовегетативні } \\
\text { порушення }\end{array}$ & 4,3 & 6,14 & 0,027 \\
\hline Фаза виснаження & 29,3 & 34,9 & 0,045 \\
\hline
\end{tabular}


ТАБЛИЦЯ 2 - Психологічні чинники формування емоційного вигорання згідно з множинним регресійним аналізом (В-коефіцієнт, $\mathrm{p}=0.01 \%$ )

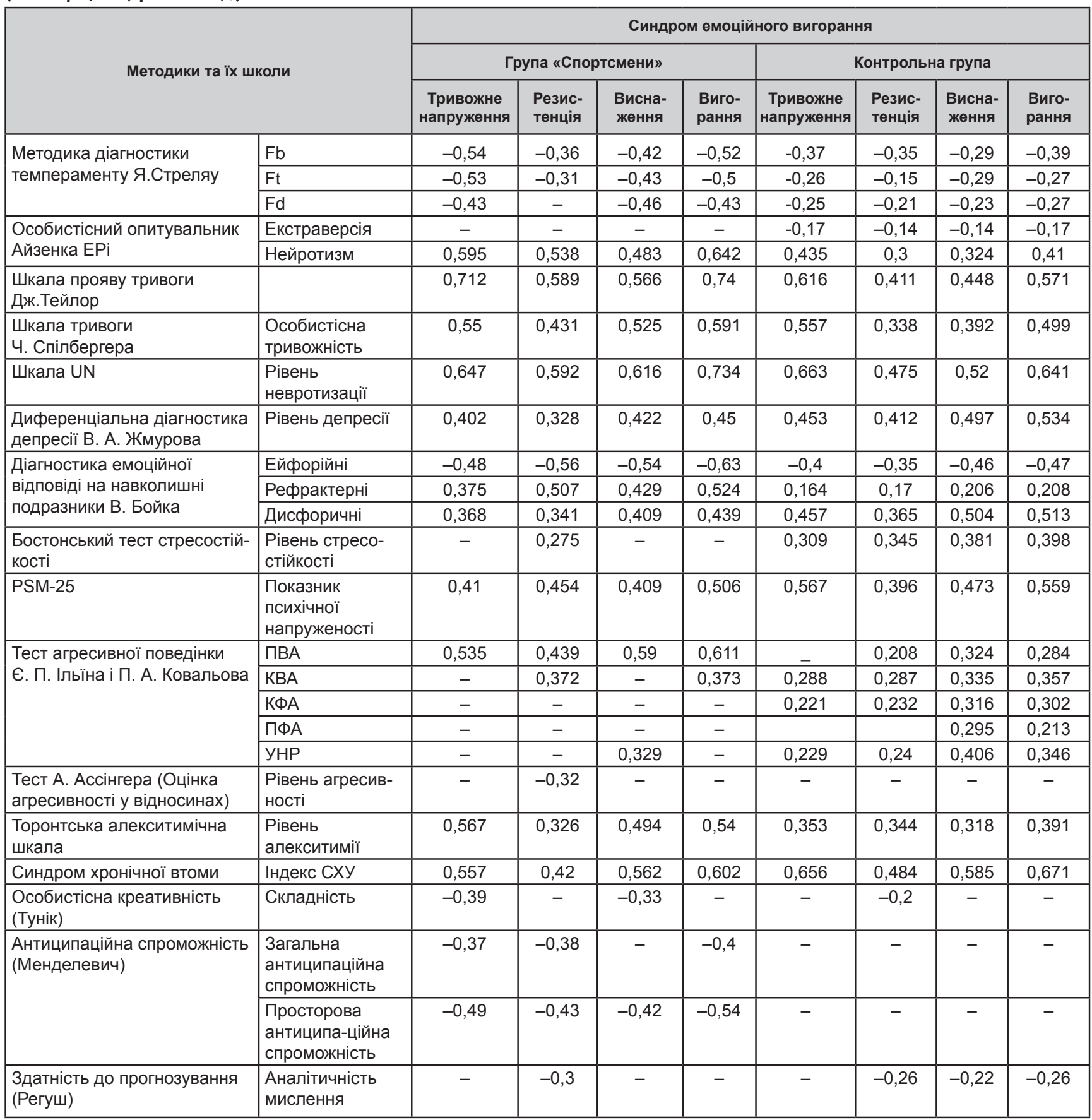

Проведений регресійний аналіз дозволив виявити психологічні фрактори фрормування емоційного вигорання (табл. 2).

На розвиток напруження - першої стадії емоційного вигорання - у студентів, які займаються спортом, впливають такі особистісні властивості, як тривожність, алекситимія, депресивність, нестриманість, хронічна втома. Перешкоджатиме виникненню напруження пряма фізична агресія та антиципація. Проявлятись це буде окрім за- гальних симптомів напруження ще і зростанням прямої вербальної агресії, зниженням мотивації та змінами в сорері соціального спілкування.

На розвиток напруження у студентів, що не займаються спортом, будуть впливати тривожність, невротичність, психологічний стрес, хронічна втома, фрізичний дискомфорт, депресивність. Окрім загальних симптомів напруження у цієї групи студентів дана стадія буде проявлятись ще й зростанням невербальної агресії. 
Отже, можна зробити висновки, що заняття спортом допомагають студенту пропрацювати стрес, невротичність, дозволяють розкрити фізичну агресію. Проте, імовірно, перешкоджає звичайному прояву емоцій, розвиваючи алекситимію, що, в свою чергу, впливає на розвиток напруження. Також, можна припустити, що заняття спортом свідомо обираються студентом як спосіб попередження виникнення напруження як першої стадії емоційного вигорання (через зв'язок з антиципацією).

Перехід на другу стадію емоційного вигоряння у студентів, що займаються спортом, буде відбуватись через зростання депресивності та нестриманості. Зростатиме також і пряма вербальна агресія, зниження загального самопочуття, когнітивний дисонанс. Також уберегтись від переходу до цієї стадії допоможуть антиципаційні здібності та прояв прямої фізичної агресії.

Для студентів, які не займаються спортом, перехід на другу стадію вигорання відбуватиметься через невротичність, хронічну втому, депресивність, нестриманість. У них зростатимуть фрізичний дискомфорт, порушення в емоційно-афективній сфрері та непряма вербальна агресія. Перехід на цю стадію пов'язаний також у даної групи студентів з низькою силою збудження, що вказує на слабку і запізнілу реакцію на порушення, повільність у включенні в роботу, впрацьовування i невисоку продуктивність праці; високу стомлюваність; низьку працездатність і витривалість.

I, нарешті, перехід на третю стадію - стадію виснаження - у студентів, які займаються спортом, відбуватиметься через вплив депресивності, нестриманості та хронічної втоми. Попередити цю стадію допоможе пряма рухова активність та високий рівень рухливості нервових процесів.

\section{Література}

1. Вашека ТВ, Тукаєв СВ. Детермінанти емоційного вигоряння студентів-психологів в процесі навчання. Проблеми загальної та педагогічної психології [Determinants of emotional burnout of students-psychologists in the learning process. Problems of general and pedagogical psychology]. 2011:4755 .

2. Водопьянова НЕ. Старченкова ЕС, Синдром выгорания: диагностика и профилактика [Burnout syndrome: diagnosis and prevention]. $-2-\mathrm{e}$ изд. Практическая психология. СПб.: Питер; 2008.

3. Тукаев СВ, Долгова ЕН, Вашека ТВ, Федорчук СВ, Лысенко ЕН, Гаврилец ЮД, Зима ИГ, Ризун ВВ, Колосова ЕВ, Шинкарук ОА. Индивидуально-психологические характеристики учащейся молодежи, занимающейся разными видами спорта [Individual psychological characteristics of student youth involved in various sports]. Спортивна медицина і фізична реабілітація. 2017;(1):64-71. doi: https://doi.org/10.32652/spmed.2017.1.64-71

4. Тукаев СВ, Вашека ТВ, Зима ИГ. Психологические и нейрофизиологические аспекты развития синдрома эмоционального выгорания. Актуальные аспекты внутренней медицины [Psychological and neurophysiological aspects of the development of burnout syndrome. Current
Проявлятись ця стадія буде окрім загальних проявів стадії виснаження ще й прямою вербальною агресією та порушеннями в емоційно-афективній copepi.

Студенти, які не займаються спортом, будуть потрапляти на третю стадію через вплив таких рис, як невротичність, хронічна втома, низька сила гальмування, депресивність, креативність. Супроводжуватиметься дана стадія у цих студентів порушеннями в емоційно-арективній сфері, прямою та непрямою вербальною агресією. Появу креативності у даному списку можна пояснити тим, що вона пов'язана з допитливістю, прагненням ризикнути і розібратись у складних запитаннях, що, відповідно, буде підсилювати виснаження особистості.

Отже, важливим $\epsilon$ те, що у складі чинників виникнення емоційного вигорання у студентівспортсменів $\epsilon$ алекситимія та нестриманість, а у студентів, що не займаються спортом, - невротичність та психологічний стрес. Проявлятись у студентів першої групи вигорання буде через пряму вербальну агресію, студентів другої групи - непряму вербальну агресію. Важливим $\epsilon$ і те, що дослідження розкрило чинники зменшення вигорання у студентів, що займаються спортом. Такими чинниками $є$ антиципація та розрядка прямої фрізичної агресії. Чинників попередження вигорання студентів, що не займаються спортом, виявлено не було.

\section{Висновки}

Отримані дані дозволяють стверджувати, що спорт має значний позитивний вплив на емоційний и псіхічній стан людини, захіщаючі псіхіку від дії стресорів, навчаючі спортсменів справлятися з труднощами, привносячи гармонію у фрізичне та психічне буття.

aspects of internal medicine]: [коллективная научная монография]. 2013 86-107.

5. Blaydon MJ, Linder KJ, Kerr JH. Metamotivational characteristics of exercise dependence and eating disorders in highly active amateur sport participants. Personality and Individual Differences. 2004 Apr 1;36(6):1419-32. doi: http://dx.doi.org/10.1016/S0191-8869(03)00238-1

6. Coakley J. Burnout among adolescent athletes: A personal failure or social problem? Sociology of sport journal. 1992 Sep 1;9(3):271-85. doi: http:// dx.doi.org/10.1123/ssj.9.3.271

7. Cresswell SL, Eklund RC. Motivation and burnout in professional rugby players. Research quarterly for exercise and sport. 2005 Sep 1;76(3):370-6 doi: 10.1080/02701367.2005.10599309

8. Cresswell SL, Eklund RC. Motivation and burnout among top amateur rugby players. Medicine and Science in Sports and Exercise. 2005 Mar 1;37(3):469-77. doi: 10.1249/01.MSS.0000155398.71387.C2

9. Cresswell SL, Eklund RC. The convergent and discriminant validity of burnout measures in sport: A multi-trait/multi-method analysis. Journal of sports sciences. 2006 Feb 1;24(2):209-20. 
10. Deci EL, Ryan RM. Self-Determination Theory. Handbook of Theories of Social Psychology: Volume One. 2012 Aug 3:416-37.

11. DeFreese JD, Raedeke TD, Smith AL. Athlete burnout: an individual and organizational phenomenon. Applied sport psychology: Personal growth to peak performance. 2015;444-61.

12. Eklund RC, DeFreese JD. Athlete burnout: What we know, what we could know, and how we can find out more. International Journal of Applied Sports Sciences. 2015 Dec 1;27(2):63-75.

13. Galli N, Gonzalez SP. Psychological resilience in sport: A review of the literature and implications for research and practice. International Journal of Sport and Exercise Psychology. 2015 Jul 3;13(3):243-57.

14. Goodger K, Gorely T, Lavallee D, Harwood C. Burnout in sport: A systematic review. The sport psychologist. 2007 Jun 1;21(2):127-51. doi: http:/l dx.doi.org/10.1123/tsp.21.2.127

15. Goodger K, Lavallee D, Gorely T, Harwood C. Burnout in sport: Understanding the process-from early warning signs to individualized intervention. Applied sport psychology: Personal growth to peak performance. 2010: 492-511.

16. Hardin R, Zakrajsek R, Gaston B. The relationship between job satisfaction and burnout in fast-pitch softball coaches. Journal of Contemporary Athletics. 2015;9(1):1-14.

17. Isoard-Gautheu S, Guillet-Descas E, Gaudreau P, Chanal J. Development of burnout perceptions during adolescence among high-level athletes: A developmental and gendered perspective. Journal of sport and exercise psychology. 2015 Aug 1;37(4):436-48.

18. Lamont-Mills A, Terry PC, Christensen SA. Re-evaluating athlete burnout in pre-elite, adolescent athletes: An Australian experience. International Congress on Sports Science and Yoga: Mission Olympic-2028. 2017. doi: 10.13140/RG.2.2.12108.00644

19. Livingston LA, Forbes SL. Factors contributing to the retention of Canadian amateur sport officials: Motivations, perceived organizational support, and resilience. International Journal of Sports Science \& Coaching. 2016 Jun;11(3):342-55. doi: 10.1177/1747954116644061

20. Lonsdale C, Hodge K, Rose E. Athlete burnout in elite sport: A selfdetermination perspective. Journal of sports sciences. 2009 Jun 1;27(8):78595. doi: http://dx.doi.org/10.1080/02640410902929366

21. Martinent G, Decret JC. Burnout, stress and recovery as predictors of performance: a longitudinal study among youth international table tennis players. International Journal of Table Tennis Sciences. 2011;7:78-9.

22. Martínez-Alvarado JR, Guillén García F, Feltz D. Athletes' motivational needs regarding burnout and engagement. Revista de psicologia del deporte. 2016;25(1):0065-71.

23. Maslach C. Understanding job burnout. Stress and quality of working life: Current perspectives in occupational health. 2006:37-51.

24. Perreault S, Gaudreau P, Lapointe MC, Lacroix C. Does it take three to tango? Psychological need satisfaction and athlete burnout. International Journal of Sport Psychology. 2007;38(4):437-50.

25. Radchuk O, Tukaiev S, Krizhanovskiy S, Vasheka T. Typological and personal determinants of burnout in students. International journal of psychology. 2012 Jan 1;47:603.

lanasvet778899@gmail.com
26. Radchuk O, Tukaiev S, Vasheka T, Kryzhanovskiy S, Ivanyuk M. The relationship between anticipatory consistency, typological and personality traits in students: P2273. European Journal of Neurology. 2012 Sep;19:548.

27. Raedeke TD, Smith AL. Development and preliminary validation of an athlete burnout measure. Journal of sport and exercise psychology. 2001 Dec;23(4):281-306. doi: 10.1123/jsep.23.4.281

28. Raedeke TD, Smith AL. Coping resources and athlete burnout: An examination of stress mediated and moderation hypotheses. Journa of sport and exercise psychology. 2004 Dec 1;26(4):525-41. doi: https://doi. org/10.1123/jsep.26.4.525

29. Rainey DW. Stress, burnout, and intention to terminate among umpires. Journal of Sport Behavior. 1995;18(4):312-23. Retrieved from http://faculty.coe.unt.edu/sites/faculty/files/39/42/Stress-Burnout-TerminateUmpires.pdf

30. Ridinger LL. Contributors and constraints to involvement with youth sports officiating. Journal of Amateur Sport. 2015 Nov 14;1(2):103-27. doi: https://doi.org/10.17161/jas.v1i2.4946

31. Ryan RM, Deci EL. Overview of self-determination theory: An organismic dialectical perspective. Handbook of self-determination research. 2002:3-33. Retrieved from http://www.elaborer.org/cours/A16/lectures/ Ryan2004.pdf

32. Serra de Queiroz F, Lima Fogaça J, Hanrahan SJ, Zizzi S. Sport psychology in Brazil: Reflections on the past, present, and future of the field. International Journal of Sport and Exercise Psychology. 2016 Apr 2;14(2):16885. doi: http://dx.doi.org/10.1080/1612197X.2016.1154090

33. Taylor AH, Daniel JV. Sources of stress in soccer officiating: An empirical study. WORLD CONGRESS OF SCIENCE AND FOOTBALL. 1987; 538-44

34. Tukaev SV, Vasheka TV, Dolgova OM. The relationships between emotional burnout and motivational, semantic and communicative features of psychology students. Procedia-Social and Behavioral Sciences. $2013 \mathrm{Ju}$ 3;82:553-6. doi: 10.1016/j.sbspro.2013.06.308

35. Tukaiev S, Vasheka T, Kryzhanovskyi S, Dolgova O, Zima I. The relationship between engagement in amateur sports and individual psychological characteristics of university students. Journal of the Neurological Sciences. 2013 Oct 15;333:e612-3.

36. Tukaiev S, Dolgova O, Lysenko O, Fedorchuk S, Havrylets Y, Rizun V, Vasheka T, Van den Tol AM. Amateur sport and emotional burnout formation in high school students. Contemporary Educational Researches Journal. 2019 Nov 31;9(4):103-9. doi: https://doi.org/10.18844/ceri.v9i4.4328

37. Verardi CE, Nagamine KK, Domingos NA, De Marco A, Miyazaki MC. Burnout and pre-competition: A study of its occurrence in Brazilian socce players. Revista de Psicología del deporte. 2015;24(2):259-64. Retrieved from http://www.redalyc.org/pdf/2351/235141413008.pdf

38. Wylleman $P$, Lavallee $D$. A developmental perspective on transitions faced by athletes. Developmental sport and exercise psychology: A lifespan perspective. 2004:507-27. 